\section{Janny Fung*}

ABB Aquaculture Equipment Ltd., China

*Corresponding Author: Janny Fung, ABB Aquaculture Equipment Ltd., China
Received: February 17, 2020

Published: February 27, 2020

(c) All rights are reserved by Janny Fung.

DOI: $10.31080 /$ ASAG.2020.04.0817

\section{Preparation for tilapia}

Take 10 Chinese mu, each Chinese mu is $667 \mathrm{~m}^{2}$, pond as an example, the water depth is 3 meters. Drain the pond water before stocking, and let it be exposed to strong light for at least 7 days. During the period, ponds, bottoms, and drainage and drainage systems of ponds should be cleaned. Clear the wild fish in the pond to prevent the wild fish and the stocking fish from competing for feed and water space. Clear the trees, water and grass residues and other debris that were inundated by the water in the pond and remove the mud once a year.

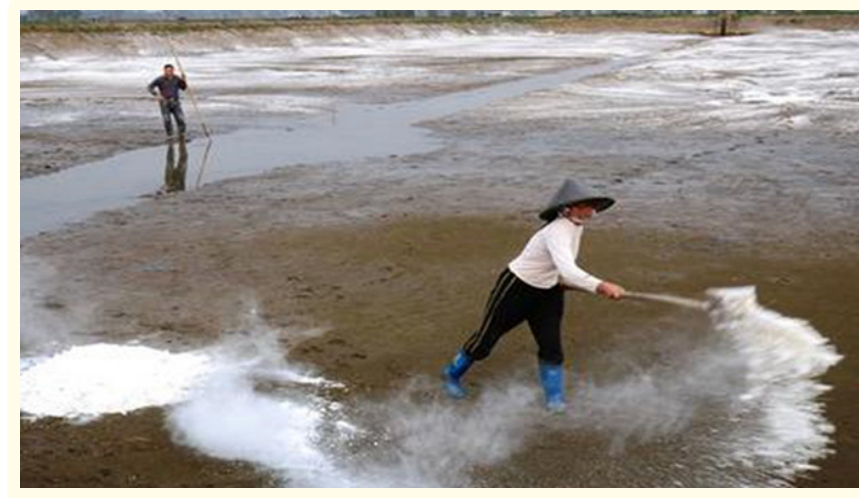

Figure 1

Dry pond clear pond per Chinese mu (667m2). The amount of quicklime is $100 \sim 200 \mathrm{~kg} / \mathrm{mu}$. Do not enter new water within 3 days after the clear pond. If the water body is weakly acidic at the early stage of the cultivation, lime 20 to $30 \mathrm{~kg}$ per lime per Chinese $\mathrm{mu}(667 \mathrm{~m} 2)$ of water shall be poured to adjust the alkalinity; by controlling the algae density, adjust the $\mathrm{pH}$ range of 6.5 8.5. Ensure that the dissolved oxygen in the pond water is sufficient for the growth of Tilapia when the dissolved oxygen water is $>3 \mathrm{mg} / \mathrm{L}$. Dissolved oxygen $<3 \mathrm{mg} / \mathrm{L}$, start aerator, open at noon on sunny days, open on cloudy days at midnight, each time 1 4 hours.

\section{Fry cultivation}

The suitable water temperature for Tilapia growth was $18^{\circ} \mathrm{C}$ $38^{\circ} \mathrm{C}$, and the optimum water temperature was $28^{\circ} \mathrm{C}-32^{\circ} \mathrm{C}$.

Choose Tilapia fry with smooth body surface, healthy body, full body of fish, neat size, high male rate, and size about $5 \mathrm{~cm}$. The 12-mesh fish filter was used for sorting. It was selected at 9 o'clock on the sunny day. It is forbidden to operate at noon or in the afternoon. Sorting is carried out using bamboo fish filter, which are divided into ponds of different sizes for stocking. After 7 days, the seedlings were released. Using high-density rearing, 1500 pcs of Tilapia fingerlings per Chinese $\mathrm{mu}\left(667 \mathrm{~m}^{2}\right)$ was placed. At the same time, larvae were stocked with 100 pcs of squid at a length of 12 - 16 $\mathrm{cm}, 50$ pcs of squid, and 15 pcs of spotted turtles.

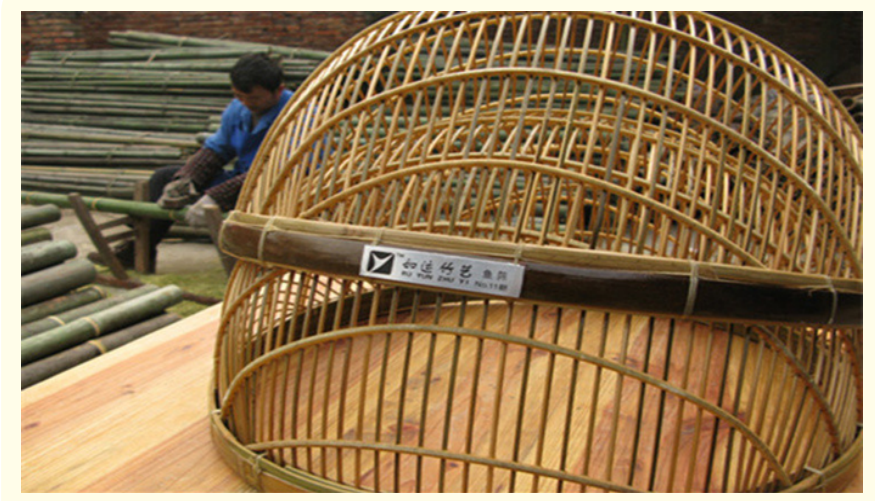

Figure 2

\section{Daily management}

In the middle term, new water should be added in a timely manner to regulate water quality. To constantly observe the changes in water quality, according to the actual situation, in accordance with the water quality control technology measures. The indicators for control were: ammonia nitrogen $\leq 0.3 \mathrm{mg} / \mathrm{L}$, dissolved oxygen $3 \sim 7$ $\mathrm{mg} / \mathrm{L}$, transparency $30 \sim 50 \mathrm{~cm}, \mathrm{pH} 7 \sim 8.5$. Fill the pond with fresh water every 3 to 4 days, 20 to 30 centimeters each time. When water quality deteriorates, change the water as soon as possible, drain the pond water first $1 / 3$ to $1 / 2$, and then add new water until the water quality becomes better. At regular intervals, the $\mathrm{pH}$ of the pool water can always be maintained at between 7.5 and 8.5, and the transparency can be maintained at 25 to 30 centimeters by flooding the whole pool with $10-15 \mathrm{mg} /$ litre of quicklime. When new water is added, new water should be filtered and the wild fish should be filtered out to prevent other Tilapia from breeding and mixing in the pond. Affect the growth and Tilapia capacity.

\section{Feeding}

Below $200 \mathrm{~g} / \mathrm{pc}$, the protein content of the feed fed Tilapia should be $32 \%$ to $35 \%$, and the daily feeding amount is $3 \%$ to $5 \%$ of the total fish body weight. When the individual specifications grow to about $200 \mathrm{~g} / \mathrm{pc}$, the amount of feed can be adjusted to $2 \%$ of the total fish body weight and ensure that the protein content in the feed is between $27 \%$ and $29 \%$. When individuals reached 

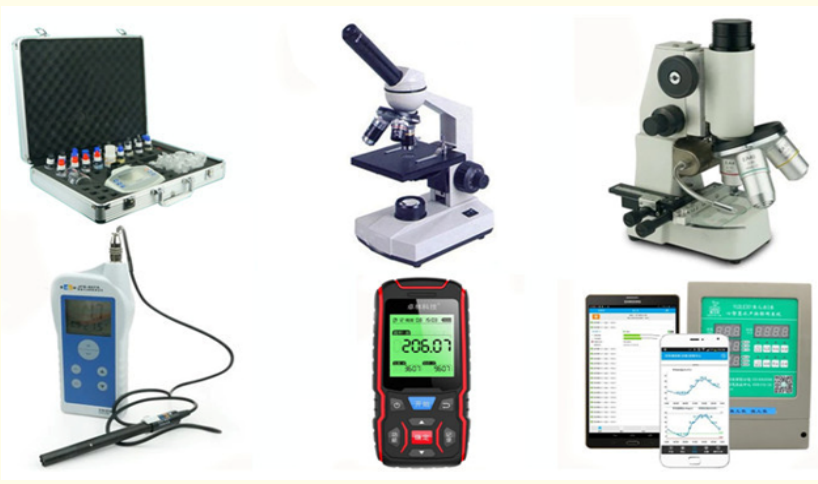

Figure 3

about $300 \mathrm{~g} / \mathrm{pc}$, Tilapia entered the fastest growing period, with daily feeds maintained at $1 \%$ to $2 \%$ of fish's body weight and protein content of feeds above $35 \%$. Feed 2 times each single day at 8 am to 9 am and $3 \mathrm{pm}$ to $4 \mathrm{pm}$.

\section{Machinery and equipment}

For example, $10 \mathrm{mu}$ of ponds, one to two aerators and one $\mathrm{Au}$ tomatic fish feeder.
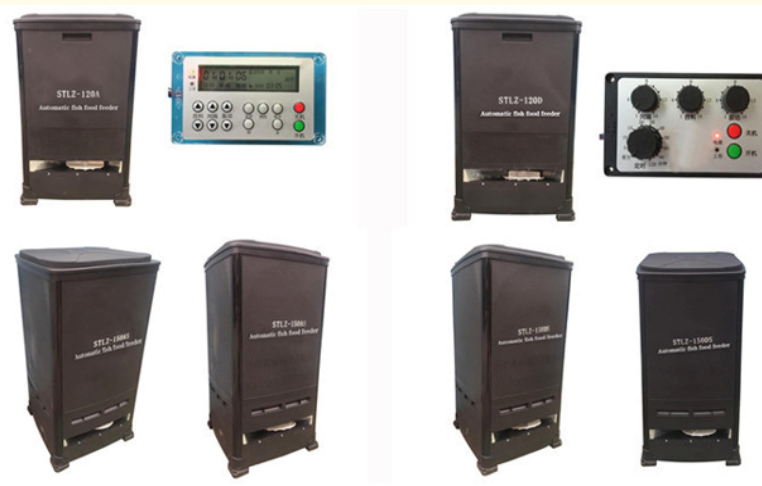

Figure 4

\section{Precautions}

As the water temperature rises, in addition to the use of fresh water to adjust the water quality, aerators must also be reasonably used to increase the dissolved oxygen content in the water. In the high temperature season, insist on starting the aerator for 1 2 hours in the sunny afternoon, you can postpone nighttime hypoxia. For high density aquaculture ponds, usually aerators are started at night, especially in the case of rainy weather or sudden changes in the weather, the boot can prevent the death of large numbers of hypoxia.

\section{Assets from publication with us}

- Prompt Acknowledgement after receiving the article

- Thorough Double blinded peer review

- Rapid Publication

- Issue of Publication Certificate

- High visibility of your Published work

Website: www.actascientific.com/

Submit Article: www.actascientific.com/submission.php Email us: editor@actascientific.com

Contact us: +919182824667

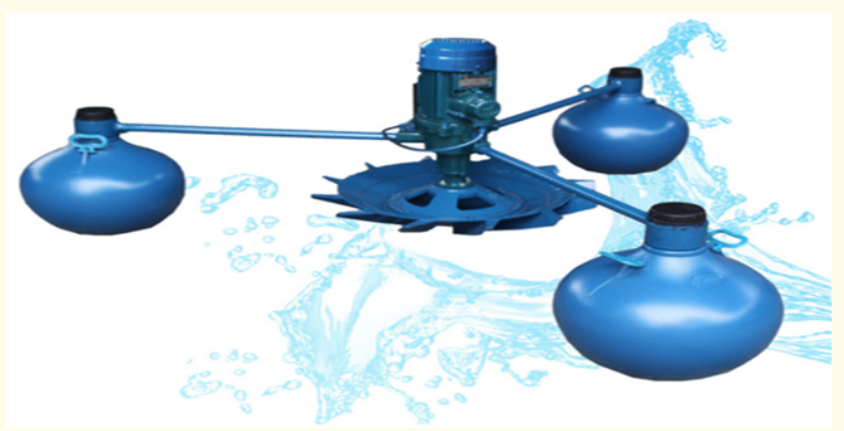

Figure 5 